\title{
Zirconia Reduced Graphene Oxide Nano-Hybrid Structure Fabricated by the Hydrothermal Reaction Method
}

\author{
Anton Smirnov ${ }^{1, *}$, Nestor Washington Solís Pinargote ${ }^{1}{ }^{\oplus}$, Nikita Peretyagin ${ }^{1}$, \\ Yuri Pristinskiy ${ }^{1}$, Pavel Peretyagin ${ }^{1}$ (D) and José F. Bartolomé ${ }^{2, * \mathbb{D}}$ \\ 1 Spark Plasma Sintering Research Laboratory, Moscow State University of Technology “STANKIN", \\ Vadkovsky per. 1, Moscow 127055, Russia; nw.solis@stankin.ru (N.W.S.P.); n.peretyagin@stankin.ru (N.P.); \\ y.pristinskiy@stankin.ru (Y.P.); p.peretyagin@stankin.ru (P.P.) \\ 2 Instituto de Ciencia de Materiales de Madrid (ICMM), Consejo Superior de Investigaciones \\ Científicas (CSIC), C/ Sor Juana Inés de la Cruz 3, 28049 Madrid, Spain \\ * Correspondence: a.smirnov@stankin.ru (A.S.); jbartolo@icmm.csic.es (J.F.B.); Tel.: +7-4999-7323-70 (A.S.); \\ +34-9133-48996 (J.F.B.)
}

Received: 22 November 2019; Accepted: 28 January 2020; Published: 4 February 2020

\begin{abstract}
In this work, we report an available technique for the effective reduction of graphene oxide (GO) and the fabrication of nanostructured zirconia reduced graphene oxide powder via a hydrothermal method. Characterization of the obtained nano-hybrid structure materials was carried out using a scanning electron microscopy (SEM), transmission electron microscopy (TEM), X-ray diffraction (XRD), Raman spectroscopy, X-ray photoelectron spectroscopy (XPS) and Fourier-transform infrared spectroscopy (FTIR). The confirmation that GO was reduced and the uniform distribution of zirconia nanoparticles on graphene oxide sheets during synthesis was obtained due to these techniques. This has presented new opportunities and prospects to use this uncomplicated and inexpensive technique for the development of zirconia/graphene nanocomposite powders.
\end{abstract}

Keywords: one-step hydrothermal synthesis; graphene oxide; zirconia nanoparticles; zirconia-reduced graphene oxide nanocomposite

\section{Introduction}

Over the past years carbon-based nanostructured materials such as carbon, CNTs (carbon nanotubes), graphene, CNFs (carbon nanofibers), fullerenes, etc. have accomplished swift evolution and extensive use because of their Van der Waals force and covalent bonding, chemical stability, and high stiffness and strength together with their low weight.

The formation of graphene [1] raised new perspectives with respect to design of new class of materials with improved characteristics with a large diversity of essential functionalities, including physical, mechanical, thermal, and optical properties as well as chemical and bioperformance [2-9].

The $\mathrm{sp}^{2}$ hybridisation that occurs during the formation of carbon atoms is in charge of its stand-out in-plane elastic and mechanical properties, namely Young modulus (0.5-1 TPa [10]) and tensile strength (130 GPa [9]). Meanwhile, a large surface area of 2D structure of graphene gives a more matrix-second phase interaction area regardless of the interaction accompanied by transfer of electrons, phonons or mechanical stresses compared to CNTs or graphite [3,11]. As a result of these remarkable properties, graphene is very attractive candidate as reinforcement phase for composites with all kinds of matrix, whether ceramic, polymer or metal.

Recently, zirconia ceramics $\left(\mathrm{ZrO}_{2}\right)$ have received significant attention from the scientific circles as a potential material for various structural applications, because of their high mechanical characteristics, 
physical and chemical wear, and thermal stability coupled with corrosion resistance and zero toxicity [12-22]. Enhancing in mechanical performance and effective control on electrical and thermal properties is a need in order for the possible future large-scale application of $\mathrm{ZrO}_{2}$.

It was stated that the presence of graphene phase can contribute to important improvements in bulk ceramic properties, such as mechanical, tribological, electrical, thermal, etc. There has been significant growth in the number of works on graphene-reinforced composites with concrete references to the various graphene synthesis techniques and processing methods of ceramic/graphene composites, including available sintering options after the isolation of graphene in 2004 [23-28]. The good bonded interfaces in matrix/graphene composites along with outstanding mechanical and the amazing structural features of graphene has been considered as a strengthening mechanism of graphene reinforcement.

Lately, graphene $/ \mathrm{ZrO}_{2}$ composites were prepared using various methods. Achieving the homogeneous distribution of graphene in the initial powder is essential to produce in order to have a uniform composite upon sintering.

For example, Liu et al. [29] and Walker et al. [30] showed that the nanostructured matrix, the GNPs (graphene nanoplatelets) generate three-dimensional cracks deflection, and the resulting in an improvement in fracture toughness. Shin and Hong fabricated reduced graphene oxide (rGO)-reinforced yttria-stabilized zirconia by spark plasma sintering, and reported a $34 \%$ increase in fracture toughness [31]. Kwon et al. demonstrated that the enhanced mechanical properties of $\mathrm{ZrO}_{2}$ composites can be achieved by addition of $3 \mathrm{wt} . \%$ graphene as a strengthening phase [32]. Chen et al. prepared graphene-reinforced zirconia ceramics using field-assisted sintering and fracture toughness values were higher in comparison to GNPs-free 3Y-TZP samples [33].

Rincón et al. produced multilaminates graphene oxide (GO)/ $8 \mathrm{~mol} \%$ yttria stabilized zirconia by colloidal processing subsequent spark plasma sintering and reported that the addition of GO-enriched layer into zirconia laminates is slowing down the probabilities of crack generation and propagation [34].

In the work of Rao et al., the surface modified graphene zirconium oxide was synthesized and characterized as a nanocomposite material. It was utilized as an adsorbent for the removal of chlorophenols from aqueous solution. The removal efficiency was maximum towards 4-chlorophenol at $\mathrm{pH} 1.0$ and decreased with increasing $\mathrm{pH}$ [35].

Teymourian et al. reported the synthesis of the high performance zirconium dioxide-reduced graphene oxide composite and its application as a novel architecture for electrochemical sensing and biosensing purposes [36].

Furthermore, Li et al. prepared zirconia/graphene nanosheets composite coatings using a plasma spraying technique. The obtained composite coating demonstrated low friction coefficient and improved wear resistance [37].

Additionally, in recent years the production of nanostructured crystalline particles has gained attention, as they possess enhanced performance abilities over conventional coarser grain materials. In order to prepare nanocrystalline zirconia-based nanocomposites, different methods such as the sol/gel method [38], vapor phase method [39], pyrolysis [40], spray pyrolysis [41], hydrolysis [42], and microwave plasma [43] have been proposed. However, these methods have many limitation factors such as complex arrangements, high temperature for the process, extended reaction time, poisonous constituents and by-products, and high costs of production, which made it difficult to prepare zirconia nanoparticles on a large-scale production.

Therefore, in order to produce effectively isolated nanoparticles with a narrower size distribution, the hydrothermal methods are mentioned as having great potential $[44,45]$. This technique is straightforward and low-cost.

All that is required for synthesis is to take a Teflon-lined stainless-steel autoclave and put the materials and precurcors in inside of it.

Uniform nucleation processes and very low grain size highlighted are highlighted as the main benefits of this method. Therefore, the purpose of this work was to produce graphene oxide (GO) with 
the subsequent production of reduced graphene oxide ( $\mathrm{rGO})$, which is used as a support to anchor zirconia nanoparticles and leading to their uniform distribution on the surface of rGO. This special nano-hybrid structure provides the opportunity to obtain a uniform composite ceramic/graphene nanopowder that can be used as a raw material to fabricate dense multi-purpose zirconia-based composites reinforced with nanostructure graphene, which combine the desired properties of each component. Thus, the aim of the present work is to obtain a nanocomposite material when there is phase uniformity and good interfacial bonding between the graphene and matrix after sintering.

\section{Materials and Methods}

\subsection{Preparation of Graphene Oxide}

Hummers' method was used as synthesis technique of graphene oxide (GO) from graphite powder which was oxidized. Briefly, this approach involves Hummer's reagents with low levels of $\mathrm{NaNO}_{3}$ and $\mathrm{KMnO}_{4}$ in concentrated $\mathrm{H}_{2} \mathrm{SO}_{4}$. Pure graphite powder was steadily added (along with $\mathrm{NaNO}_{3}$ ) into a hot concentration of $\mathrm{H}_{2} \mathrm{SO}_{4}$ solution that would be cooled in an ice bath. Afterward, $\mathrm{KMnO}_{4}$ was slowly added, in small doses, to keep the reaction temperature below $20^{\circ} \mathrm{C}$. Then the suspension was treated with a hydrogen peroxide $\left(\mathrm{H}_{2} \mathrm{O}_{2}\right)$ solution and washed with $\mathrm{HCl}$ and $\mathrm{H}_{2} \mathrm{O}$ in order to complete the reaction with $\mathrm{KMnO}_{4}$. After filtration and drying, $\mathrm{GO}$ sheets were obtained. In the previous works, this process is decribed in further detail $[28,46,47]$.

\subsection{Synthesis of $\mathrm{ZrO}_{2} / r G O$ Nanocomposite Powders}

The as-prepared GO was exfoliated ultrasonically for $2 \mathrm{~h}$ in order to obtain a stable GO colloidal suspension with a concentration of $2.33 \mathrm{mg} \cdot \mathrm{mL}^{-1}$. The synthesis of reduced graphene oxide-nanozirconia $\left(\mathrm{ZrO}_{2} / \mathrm{rGO}\right)$ composites was carried out by means of a simple hydrothermal process, in which the $\mathrm{GO}$ suspension was used as the rGO precursor, $\mathrm{N}_{2} \mathrm{H}_{4} \cdot \mathrm{H}_{2} \mathrm{O}$ and $\mathrm{ZrOCl}_{2} \cdot 8 \mathrm{H}_{2} \mathrm{O}$ acted as the reducing agent and the $\mathrm{nZrO}_{2}$ precursor, respectively. Firstly, $40 \mathrm{~mL}$ of GO colloidal suspension was mixed with $20 \mathrm{~mL}$ of a $\mathrm{ZrOCl}_{2}$ solution $(0.01 \mathrm{M})$ to obtain a mixed solution of GO and $\mathrm{ZrOCl}_{2}$ with a volume ratio of 2:1. After being sonicated for $30 \mathrm{~min}, 1 \mathrm{~mL}$ hydrazine hydrate was added to the mixture and was poured into a $200 \mathrm{~mL}$ stainless steel teflon-lined autoclave, which was sealed and maintained at $180^{\circ} \mathrm{C}$ for $18 \mathrm{~h}$, and then naturally cooled at room temperature. For the purpose of removing $\mathrm{Cl}$-ions, the obtained material was washed, centrifuged, and re-dispersed five times in deionized water. Finally, the $\mathrm{ZrO}_{2} / \mathrm{rGO}$ nanocomposite powders were dried in a FreeZone2.5 freeze-drying system (LabConco, Kansas, MO, USA). The collector temperature is continuously set at $-50 \pm 2{ }^{\circ} \mathrm{C}$.

Furthermore, the shell temperature and the chamber pressure were kept at $23 \pm 2{ }^{\circ} \mathrm{C}$ and 0.02 \pm 0.01 mbar, respectively, during the entire process [30]. For comparison purposes, non-reduced graphene oxide-nanozirconia $\left(\mathrm{ZrO}_{2} / \mathrm{GO}\right)$ composite powder was prepared following the same cycle without the addition of $\mathrm{N}_{2} \mathrm{H}_{4} \cdot \mathrm{H}_{2} \mathrm{O}$.

\subsection{Microstructural Characterization of the As-Prepared Nanocomposite Powders}

The microstructure, crystalline structure, and surface morphology characterizations of the as-synthesized samples were evaluated by transmission electron microscopy JEM 3010 (JEOL, Tokyo, Japan, accelerating voltage $200 \mathrm{kV}$ ). To this end, nanopowders were placed on a TEM grid (perforated carbon film on the copper mesh, Plano GmbH, Wetzlar, Germany) [22].

As was described previously, the particle diameter distribution of the nanocrystalline zirconia was determined from TEM micrographs by measuring the diameters of about 800 zirconia nanoparticles in both synthesized nanopowders. From these data, the density distribution of the particle diameters on number basis $\mathrm{q}_{0}$ and on surface area basis $\mathrm{q}_{2}$ were compiled. A Gaussian normal distribution was fitted to the measured distribution in order to obtain the corresponding geometric mean particle diameters $\mu_{\mathrm{g}}\left(\mathrm{q}_{0}\right)$ and $\mu_{\mathrm{g}}\left(\mathrm{q}_{2}\right)$. The cumulative distribution of the particle diameters $\mathrm{q}_{0}$ was fitted with a sigmoid 
function to obtain the characteristic particle diameter $\mathrm{d}_{50}$. The specific surface area $\mathrm{S}_{\text {TEM }}$ of the zirconia nanoparticles was calculated from $\mu_{\mathrm{g}}\left(\mathrm{q}_{2}\right)$ using the density of $5.68 \mathrm{~g} / \mathrm{cm}^{2}$ and assuming spherical particles [22]. Further, the field emission scanning electron microscopy (FE-SEM) observations were performed by LYRA3 (Tescan, Brno, Czech Republic).

2.4. X-ray Diffraction (XRD), Raman, X-ray Photoelectron Spectroscopy (XPS) and Fourier Transform Infrared (FTIR) Characterization

X-ray diffraction measurements were conducted using an Empyrean diffractometer (PANalytical, Almelo, Netherlands) ranging from $5^{\circ}$ to $70^{\circ}$. The step size was 0.05 with a scan speed of $0.06 / \mathrm{min}$. The diffractometer used $\mathrm{Cu} \mathrm{K} \alpha$ radiation $(\lambda=1.5405981)$ working at $40 \mathrm{kV}$ and with an intensity of $30 \mathrm{~mA}$ [48].

Raman spectra of studied materials were collected to identify the phase composition. The Raman setup is composed of a laser (DXR ${ }^{\mathrm{TM}} 2$ Raman Microscope, Thermo FisherScientific, Waltham, MA, USA) with a wavelength of $532 \mathrm{~nm}$ and a laser power of $2.0 \mathrm{~mW}$. The laser beam was focused through an optical microscope's $50 \times$ objective lens to a spot size of $2 \mu \mathrm{m}$ on the studied area (from different spots, at an interval of $10 \mu \mathrm{m}$ ). The accumulation time for each Raman spectrum was about $10 \mathrm{~s}$ [26].

All X-ray photoelectron spectroscopy (XPS) measurements were carried out on a K-Alpha (Thermo FisherScientific, Waltham, MA, USA) photoelectron spectrometer equipped with a micro-focused monochromator $\mathrm{Al} \mathrm{K} \alpha \mathrm{X}$-ray source. Peak fitting of the $\mathrm{C} 1$ s and $\mathrm{Zr} 3 \mathrm{~d}$ spectra for $\mathrm{ZrO}_{2} / \mathrm{rGO}$ and ZrO $2 / G O$ nanopowders were conducted separately using a Gaussian-Lorentzian function after performing a Shirley background correction.

Fourier transform infrared (FTIR) spectra of the synthesized nanocomposite powders were measured (Vertex 70 spectrometer, Bruker AXS Inc., Madison, WI, USA) in the wavenumber range $500 \mathrm{~cm}^{-1}$ to $4000 \mathrm{~cm}^{-1}$ (transmission mode, resolution $2 \mathrm{~cm}^{-1}, 120$ scans per sample). For this purpose, potassium bromide $(\mathrm{KBr})$ pellets (diameter $1.0-1.3 \mathrm{~cm}$ ) of each powder sample were prepared using a uniaxial press [49].

\section{Results and Discussion}

The nanozirconia crystals have a particularly spherical shape and they are uniformly dispersed. Almost no difference was found in particle size distribution and specific surface area. The geometric mean diameters $\mu_{\mathrm{g}}\left(\mathrm{q}_{0}\right)$ and $\mu_{\mathrm{g}}\left(\mathrm{q}_{2}\right)$ of the particle size distribution are $5.1 \mathrm{~nm} \pm 0.8 \mathrm{~nm}$ and $4.8 \mathrm{~nm} \pm 1.2 \mathrm{~nm}$, respectively, and the $\mathrm{d}_{50}$ diameter is $5.0 \mathrm{~nm}$ with an uncertainty of $\pm 0.8 \mathrm{~nm}$ for both $\mathrm{ZrO}_{2} / \mathrm{GO}$ and for $\mathrm{ZrO}_{2} / \mathrm{rGO}$ nanopowders. The specific surface area $\mathrm{S}_{\mathrm{TEM}}$ of the nanopowders was calculated from the geometric mean diameter $\mu_{\mathrm{g}}\left(\mathrm{q}_{2}\right)$ and reached a value of $110.0 \mathrm{~m}^{2} / \mathrm{g}$.

Figure 1 shows a representative diffraction pattern of a fabricated nanopowders.

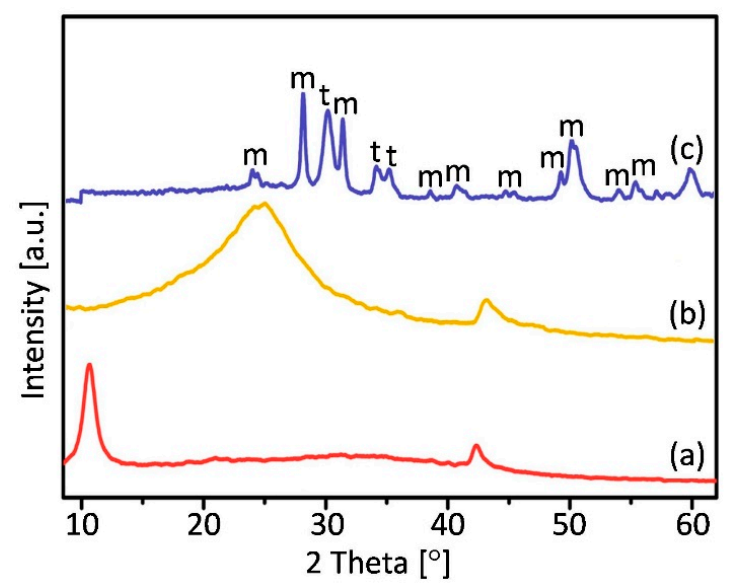

Figure 1. XRD patterns of (a) GO (b) $\mathrm{rGO}$ and (c) $\mathrm{ZrO}_{2} / \mathrm{rGO}$ materials, where " $\mathrm{m}$ " and " $\mathrm{t}$ " denote monoclinic and tetragonal zirconia, respectively. 
The most intense apparent peak located at $2 \theta=10.8^{\circ}$ in the curve of $\mathrm{GO}$, and corresponds to the (001) reflection of GO [50]. The result confirms the oxidation and the fact that raw graphite was converted into graphene oxide becouse of the appearance of oxygen-containing functional groups [51]. The rGO pattern accompanied with a major (002) peak centered at around $25^{\circ}$ assigned to the reduction of GO sheets and restacking into an ordered crystalline structure [52]. On the X-Ray diffractogram of $\mathrm{ZrO}_{2} / \mathrm{rGO}$ nanocomposite powder diffraction peaks in the region up to $20^{\circ}$ are not presented as indicated in the case of GO and enables to say that the GO was well reduced during the reaction. In addition, analys of intensities and peaks location appearing in XRD data were compared with the infromation from the International Centre for Diffraction Data (ICDD) for tetragonal (PDF file no.01-083-0113) and monoclinic (PDF file no. 00-024-1165) structures.

The Raman spectra of all the studied materials are shown in Figure 2.

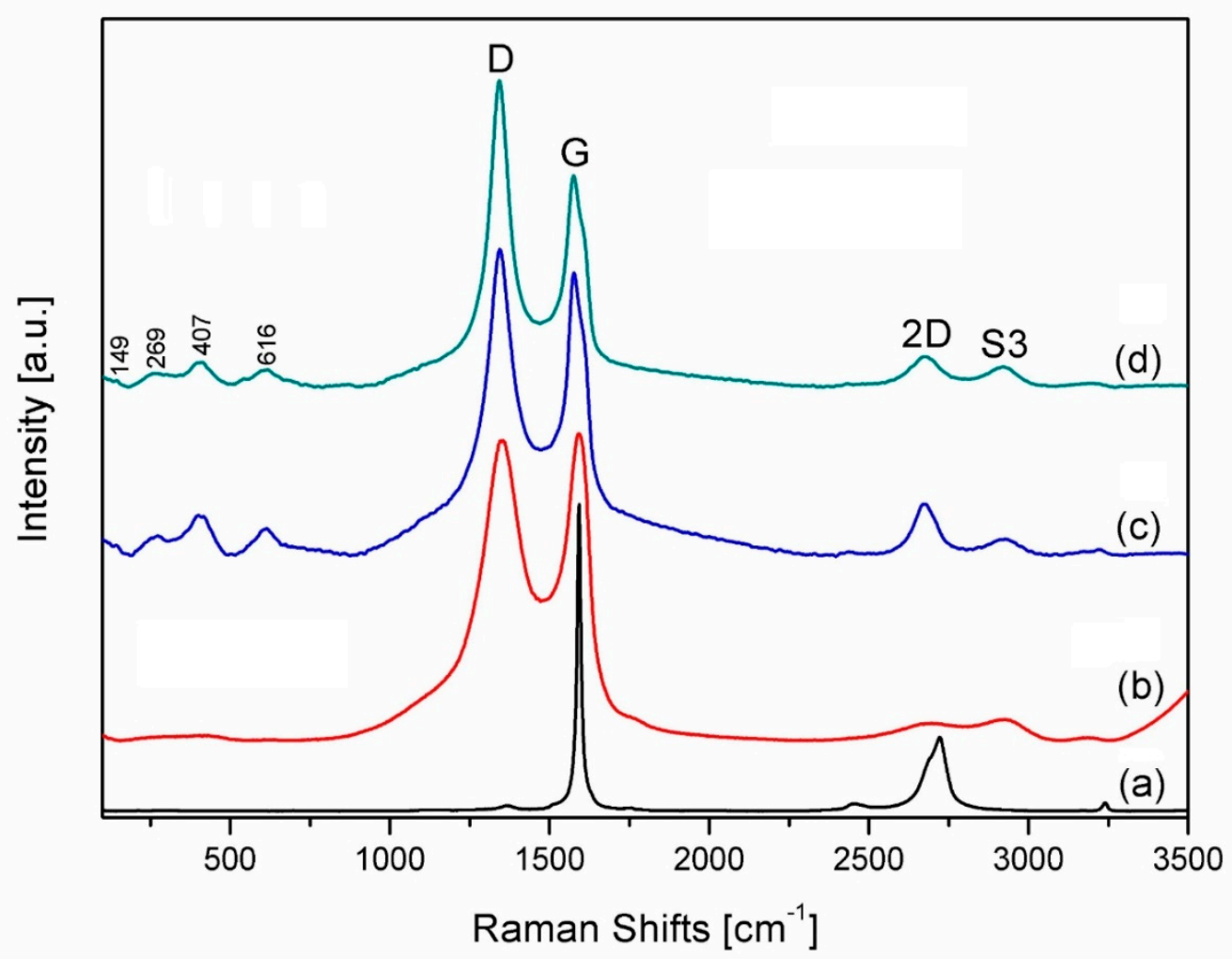

Figure 2. Raman spectra of starting graphite powder (a), graphene oxide (b), synthesized $\mathrm{ZrO}_{2} / \mathrm{GO}$ (c) and $\mathrm{ZrO}_{2} / \mathrm{rGO}(\mathbf{d})$ nanopowders. " $\mathrm{D}$ ", “ $\mathrm{G}$ ", “2D" and "S3" correspond to the graphene-based structure.

Raman spectrum of the graphite sample shows the characteristic peaks for this material. For instance, the peak located at $\sim 1584 \mathrm{~cm}^{-1}$ is the $\mathrm{G}$ band and it is the more intence than the $2 \mathrm{D}\left(2720 \mathrm{~cm}^{-1}\right)$ and $\mathrm{D}\left(\sim 1350 \mathrm{~cm}^{-1}\right)$ bands (Figure 1a). In the case of graphene (Figure 1b-d), a imperceptible second-order zone and a broad $\mathrm{G}$ peak are peculiarity of hybridized carbon-carbon bonds $\left(\mathrm{sp}^{1}, \mathrm{sp}^{2}\right.$ and $\mathrm{sp}^{3}$ ) [24]. The more intense D bands (Figure $2 \mathrm{c}, \mathrm{d}$ ) at $\sim 1350 \mathrm{~cm}^{-1}$ means that $\mathrm{sp}^{2}$ bonds were broken and, consequently, it indicates that a intended transformation of $\mathrm{sp}^{2}$ hybridization to $\mathrm{sp}^{3}$ was occurred, which shows a rise of the disorder in the $\mathrm{sp}^{2}$-hybridized carbon system [26]. This difference in intensity between $\mathrm{D}$ and $\mathrm{G}$ bands is particularly marked in $\mathrm{ZrO}_{2} / \mathrm{rGO}$ (Figure $2 \mathrm{~d}$ ) powders, which illustrates the creation of new defects in the $\mathrm{sp}^{2}$ carbon lattice during the reduction process.

It was suggested that, besides some defects in reduced graphene oxide, the presence of $\mathrm{ZrO}_{2}$ nanoparticles onto the surface of the rGO causes additional changes in the characteristics of the vibrations in the material's lattice. Therefore, the intensity of $\mathrm{D}$ bands after the reduction process is higher in comparison to the unreduced $\mathrm{ZrO}_{2} / \mathrm{GO}$ nanocomposite powders. 
It should be noted that after the graphite's chemical oxidation process, the presence of peaks attributed to $2 \mathrm{D}$ band were not observed in GO (Figure $2 \mathrm{~b}$ ). It can be assumed that diverse kind of oxygen-containing functional groups were embedded among the graphitic sheets in their basal plane or edges, and the presence of these groups causes the breaking of the $\mathrm{sp}^{2}$ carbon lattice and consequently its structural changes. However, the elimination of oxygen containing groups leads to the restoration of ordered graphitic stacking in rGO and causes the appearance of 2D peak [53-55].

Another band, known as conjunction between D and G intensities and appears near $2900 \mathrm{~cm}^{-1}$ is a second-order peak and denoted by S3.

$\mathrm{S} 3 / 2 \mathrm{D}$ intesity ratio is related to the diminution in defects and involves a lower quantity of oxygen in graphene [56]. Raman shifts at $149 \mathrm{~cm}^{-1}, 269 \mathrm{~cm}^{-1}, 407 \mathrm{~cm}^{-1}$ and $616 \mathrm{~cm}^{-1}$ were interpreted as tetragonal zirconia phases [57,58].

To investigate the chemical changes between reduced and not reduced graphene oxide powder XPS measurements have been carried out (Figure 3).
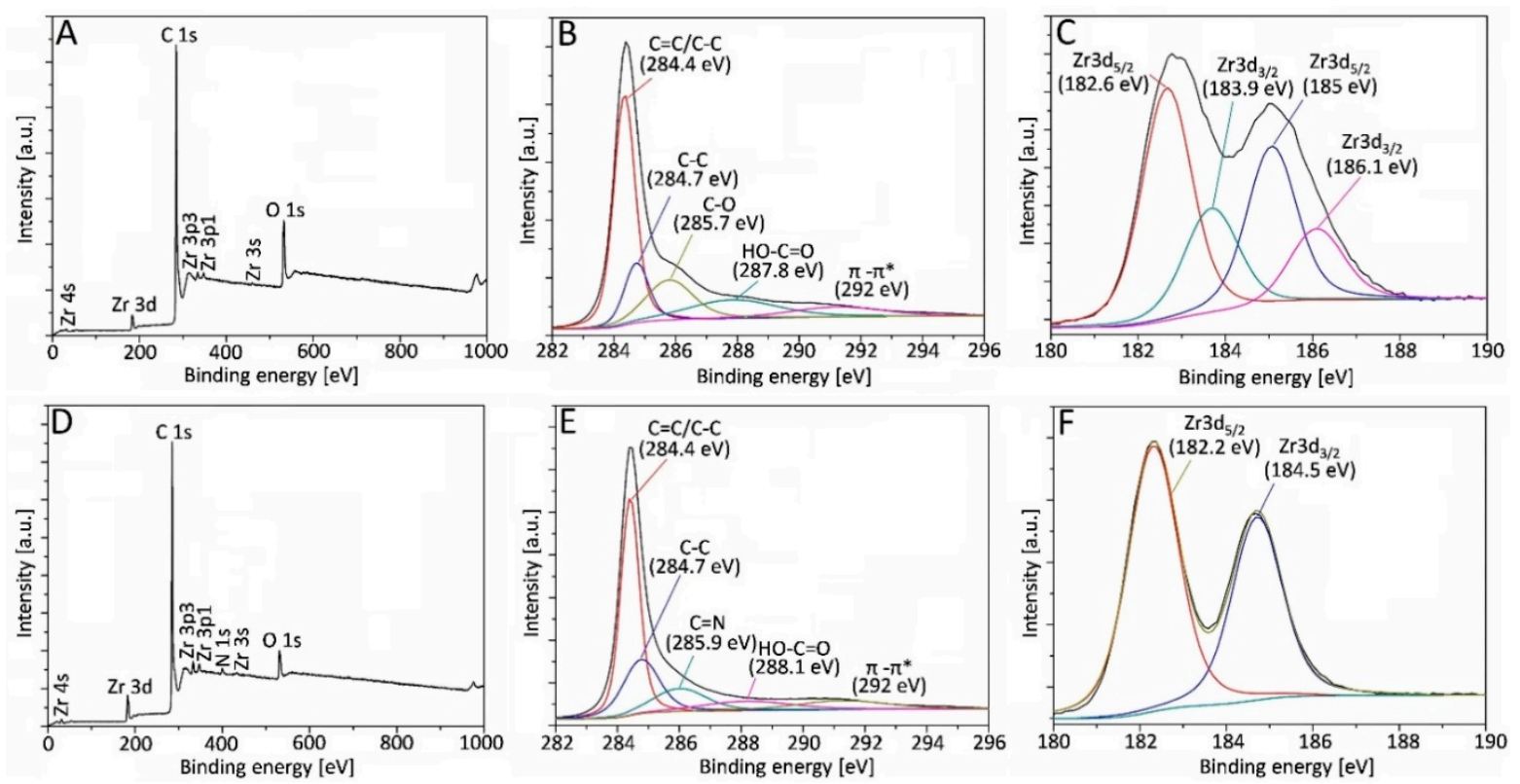

Figure 3. Survey XPS spectra (A,D), fitted spectra of C1s (B,E) and Zr3d (C,F) detailed scans for $\mathrm{ZrO}_{2} / \mathrm{GO}$ (upper row) and $\mathrm{ZrO}_{2} / \mathrm{rGO}$ (bottom row) powders.

The appearance of oxygen, zirconia, and carbon structures in the sample was confirmed by Zr3d, O1s, and C1s characteristic peaks in the full-scan XPS spectrum of $\mathrm{ZrO}_{2} / \mathrm{GO}$ (Figure 3A). However, the presence of an additional peak at $399.5 \mathrm{eV}$ that corresponds to the nitrogen bond was detected in the hydrazine-treated $\mathrm{ZrO}_{2} / \mathrm{rGO}$ sample (Figure 3D). The presence of other peaks, different to $\mathrm{Zr}$, oxygen, carbon and, in the case of $\mathrm{ZrO}_{2} / \mathrm{rGO}$ powder-nitrogen, was not found. Therefore, the processing method would be considered appropriate.

For further interpretation and to better understand the mechanism of formation and the chemical states of elements, comprehensive analysis of C and Zr XPS spectra were carried out. The detailed C1s spectra of not-reduced and chemically reduced powders are shown in Figure 3B,E, respectively. Although these obtained spectra are practically identical and show the appearance of diffent functional groups, the peak intensities in the reduced powder are smaller and consequently confirm de-oxygenation by the reduction process. The peak-fitting spectra at the binding energies of $284.4 \mathrm{eV}, 284.7 \mathrm{eV}$ and $\sim 288 \mathrm{eV}$ were assigned to carbon atoms in different functional groups: $\mathrm{C}=\mathrm{C} / \mathrm{C}-\mathrm{C}\left(\mathrm{sp}^{2} \mathrm{C}\right)$ peak, $\mathrm{C}-\mathrm{C}\left(\mathrm{sp}^{3}\right.$ C) peak and $\mathrm{C}=\mathrm{O}$ (the carbonyl groups), respectively $[59,60]$. Moreover, shake-up satellites $\left(\pi-\pi^{*}\right)$ with a binding energy of $292 \mathrm{eV}$ were observed [61-63], which is a characteristic satellite peak for carbon structures or aromatic compounds [64]. 
The occurence of these peaks confirmed the hexagonal structure of the graphene [65-68]. Meanwhile, the high resolution of the $\mathrm{C} 1 \mathrm{~s}$ spectrum of $\mathrm{ZrO}_{2} / \mathrm{rGO}$ powder had an additional peak at $285.9 \mathrm{eV}$ (Figure 3E) may be assigned to the $\mathrm{C}$ in the $\mathrm{C}=\mathrm{N}$ bond formation due to the presence of hydrazine [69], that is also proven by XPS survey spectrum (Figure 3D). High-resolution XPS spectral analysis for the $\mathrm{Zr} 3 \mathrm{~d}$ shows the spin-orbit splitting the components, $\mathrm{Zr}_{3} \mathrm{~d}_{3 / 2}$ and $\mathrm{Zr}_{3} \mathrm{~d}_{5 / 2}$, in the $\mathrm{ZrO}_{2} / \mathrm{GO}$ and $\mathrm{ZrO}_{2} / \mathrm{rGO}$ materials (Figure 3C,F, respectively). Two different chemical states of zirconia were found in the $\mathrm{ZrO}_{2} / \mathrm{GO}$ sample (Figure 3C). The first of them at $182.6 \mathrm{eV}$ can be assigned to the zirconia sub-oxide. Meanwhile, the second one relates to the binding energy and could be determined as stoichiometric $\mathrm{ZrO}_{2}$ and implies that valence of zirconium remained $\mathrm{Zr}^{4+}[70,71]$. The intensity of binding energy peak at $183.9 \mathrm{eV}$ corresponds to the formation of the zirconia. A chi-square approximation by using a doublet with spacing between lines of $2.4 \mathrm{eV}$ was obtained for $\mathrm{ZrO}_{2} / \mathrm{rGO}$ (Figure 3F). The position of the lines is attributed to the zirconia sub-oxide. The width of the lines $(1.4 \mathrm{eV})$ demonstrates the high uniformity of the stoichiometric state of the sample. It can be assumed, comparing the spectra of both samples, that the line within the binding energy interval between $182.2 \mathrm{eV}$ and $182.6 \mathrm{eV}$ correlates to zirconia thin films.

The existence of functional groups in both the raw and synthesized samples has been determined using a FTIR technique (Figure 4).

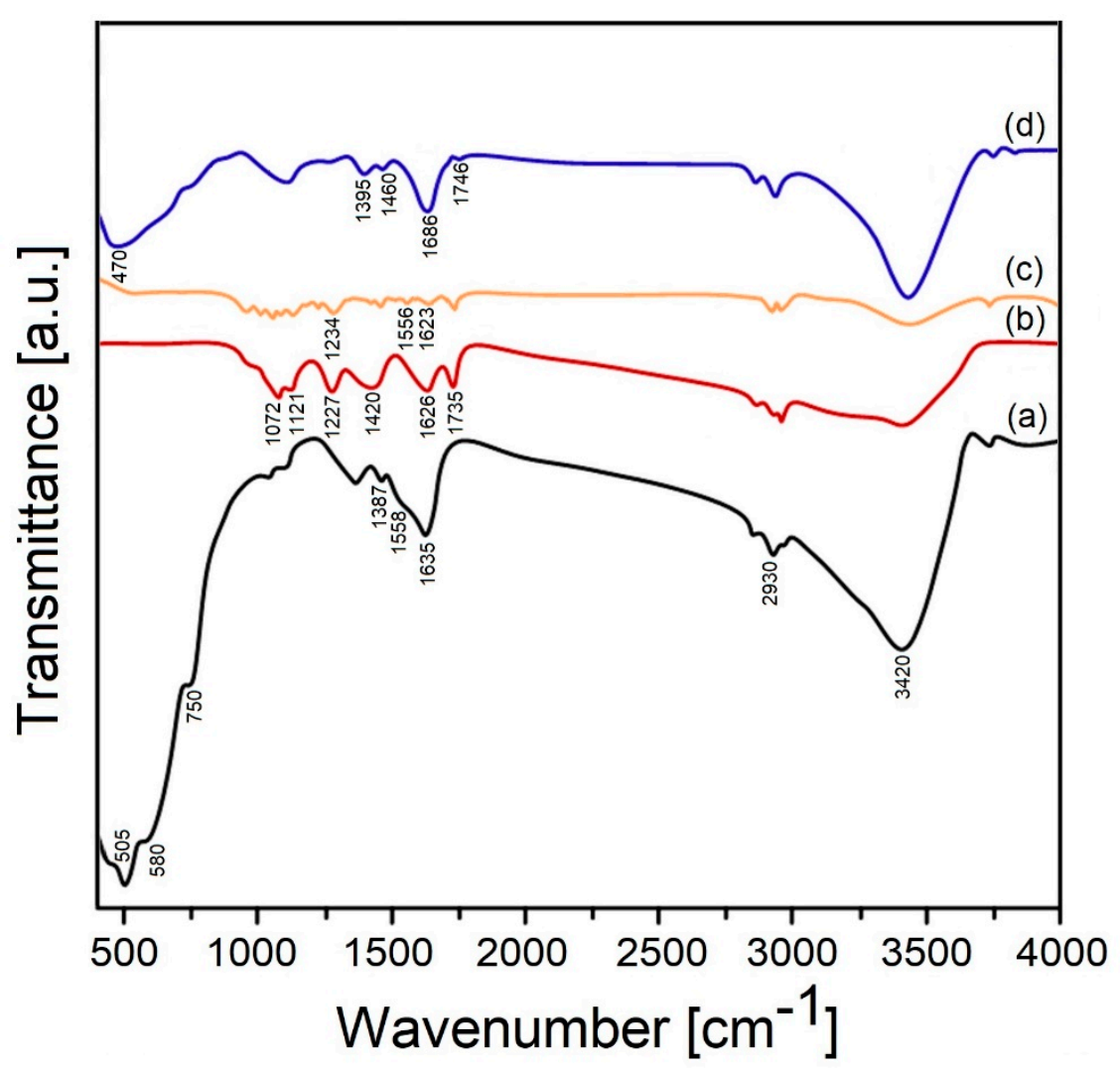

Figure 4. FTIR spectra of zirconia (a), GO (b), $\mathrm{rGO}(\mathbf{c})$ and $\mathrm{ZrO}_{2} / \mathrm{rGO}(\mathbf{d})$ nanopowders.

Obviously, the clear expresed absorption that appeared at peaks at 3420, 1635 and $1558 \mathrm{~cm}^{-1}$ correspond to the stretching $(v(-\mathrm{OH}))$ and bending $(\delta(-\mathrm{OH}))$ vibrations of coordinated or absorbed water molecules retained on the $\mathrm{ZrO}_{2}$ suface [72]. The peak appeared at $1387 \mathrm{~cm}^{-1}$ indicates the existence of $\mathrm{OH}$ deformations in the $\mathrm{C}-\mathrm{OH}$ groups [60]. The $\mathrm{Zr}-\mathrm{O}$ vibration of zirconia shows the intensities at 505, 580, and $750 \mathrm{~cm}^{-1}$ [73-75]. Meanwhile, the $\mathrm{CH}_{2}$ stretching mode demonstrates the broad absorption peaks around $2930 \mathrm{~cm}^{-1}$ [60]. 
The $\mathrm{C}=\mathrm{O}$ stretching vibration of $-\mathrm{COOH}$ and $\mathrm{C}=\mathrm{O}$ was observed at $1735 \mathrm{~cm}^{-1}$, while the $\mathrm{O}-\mathrm{H}$ bending vibration of water molecules and the $\mathrm{C}=\mathrm{C}$ skeleton stretching mode was assigned at $1626 \mathrm{~cm}^{-1}$ [76]. The $\mathrm{O}-\mathrm{H}$ bending mode of $-\mathrm{COOH}$ and $\mathrm{C}-\mathrm{OH}$ bonds show the intense peak at $1420 \mathrm{~cm}^{-1}$. The peak located at $1227 \mathrm{~cm}^{-1}$ belongs to the $\mathrm{C}-\mathrm{O}-\mathrm{C}$ stretching vibration. The absorption bands at 1121 and $1072 \mathrm{~cm}^{-1}$ corespond to the epoxy C-O and the alkoxy C-O stretching vibration, respectively [77-83]. Unlike the GO bands, the spectrum of rGO exhibits that the vibrational frequencies of peaks weakened and slightly vanished. The appearance of the absorption bands at 1623 and $1556 \mathrm{~cm}^{-1}$ was recognized to stretching of the aromatic $C=C$ mode, while the band at $1234 \mathrm{~cm}^{-1}$ corresponds to the epoxy $\mathrm{C}-\mathrm{O}$ and $\mathrm{C}=\mathrm{O}$, indicates that $\mathrm{GO}$ was reduced incompletely [72,84-86]. On the other hand, the characteristic band located at $1727 \mathrm{~cm}^{-1}$ was assigend to $\mathrm{C}=\mathrm{O}$ stretching frequency belonging to the $\mathrm{ZrO}_{2} / \mathrm{rGO}$ nanocomposite was shifted to $1746 \mathrm{~cm}^{-1}$ because the relationship between the $\mathrm{C}=\mathrm{O}$ group and $\mathrm{Zr}$ and its relative intensity was also decreased [87]. The hydrolysis of the $\mathrm{ZrOCl}_{2}$ solution provides the interaction between the oxygen-containing groups of $\mathrm{GO}$ and $\mathrm{Zr}(\mathrm{IV})$ and the appearance of two vibrational bands located at 1460 and $1395 \mathrm{~cm}^{-1}$, which were assigned to the creation of either a monodentate or bidentate complex [78-81]. The vibrational bands at 1686 and $470 \mathrm{~cm}^{-1}$ can be assigned to the $\mathrm{C}=\mathrm{C}$ stretching mode and $\mathrm{Zr}-\mathrm{O}$ vibration, respectively $[60,72]$. By this means, after the characterization of the resultant hybrid material, it can be argued that the synergies between $\mathrm{ZrO}_{2}$ nanoparticles and rGO nanosheets occured, i.e., ceramic nanoparticles were directly attached to the surface of the rGO nanosheets.

Moreover, there is even further evidence to support the findings after the various characterization techniques-the SEM and TEM images where the rGO sheets and $\mathrm{ZrO}_{2}$ nanoparticles were seen (Figure 5). The SEM image of the GO (inset of Figure 5A) exhibited the characteristic rippled, curved and crumpled sheet-like texture, whereas the SEM image of $\mathrm{ZrO}_{2} / \mathrm{rGO}$ (inset of Figure 5B) showed a uniform distribution of the $\mathrm{ZrO}_{2}$ nanoparticles, which are anchored onto flat and not curled rGO sheets. Furthermore, the EDX spectrum of GO (Figure 5A) provided peaks of $\mathrm{C}$ and $\mathrm{O}$, whereas the presence of $\mathrm{C}, \mathrm{O}$, and $\mathrm{Zr}$ in the $\mathrm{ZrO}_{2} / \mathrm{rGO}$ sample (Figure 5B) suggested the bonding of $\mathrm{ZrO}_{2}$ nanoparticles on the grapnene oxide surface. The TEM images exhibited intimate interfacial contact between rGO and $\mathrm{ZrO}_{2}$ nanoparticles (Figure 5C,D). The high resolution TEM image (Figure 5D) shows the lattice of $0.29 \mathrm{~nm}$ spacing which is very close to the lattice spacing corresponding to the (111) plane of the tetragonal structure of $\mathrm{ZrO}_{2}[36,88]$. According to the above observations, it can be said that the surface GO sheets were uniformly covered by zirconia nanoparticles synthesized via hydrothermal reaction.
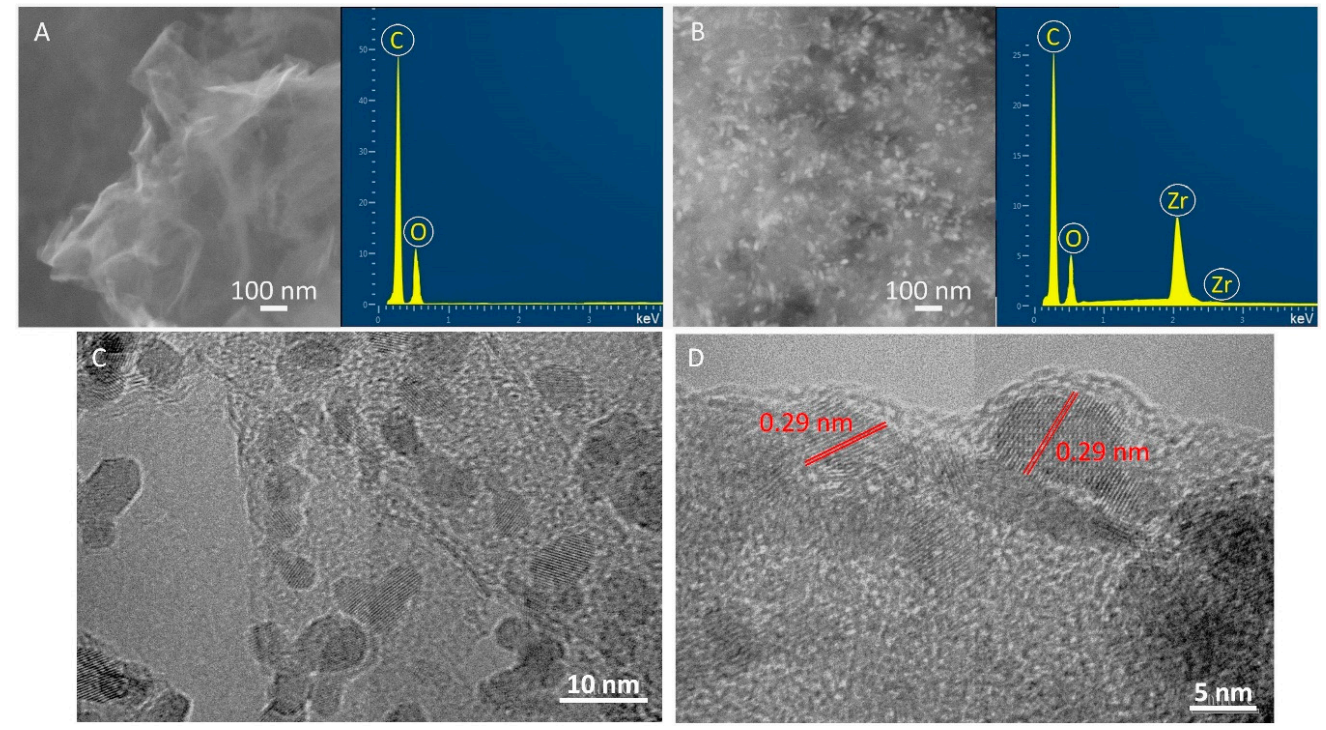

Figure 5. SEM images and EDS spectra of GO (A) and hydrothermally synthesized $\mathrm{ZrO}_{2} / \mathrm{rGO}$ nanocomposite powder (B). Representative TEM (C) and HRTEM (D) images of $\mathrm{ZrO}_{2} / \mathrm{rGO}$ nanocomposite powder. 
The development of $\mathrm{ZrO}_{2} / \mathrm{rGO}$ nanocomposite powders by the hydrothermal reaction technique provides the opportunity to design new materials with a large panoply of precise properties to fulfill specific requirements. In particular, for achieving the synergistic toughening effect, load-bearing capacity and high wear resistance in bulk multiphase ceramic-matrix composites for their application as engineering components $[28,89]$. Therefore, it is planned to focus on the fabrication of the various bulk ceramic matrix composites and to evaluate of their multifunctional properties.

\section{Summary}

In the present work, a nanostructured $\mathrm{ZrO}_{2} / \mathrm{rGO}$ powder was fabricated using a low-cost and simple method, namely the hydrothermal synthesis technique. This process can be summarized in a few steps: As a result of the $\mathrm{ZrOCl}_{2}$ solution hydrolysis process, the positively charged zirconia ions were generated and collected at a surface of negatively charged GO sheets due to electrostatic attraction. After that, the $\mathrm{ZrO}_{2} / \mathrm{rGO}$ nanocomposite powder was formed because of generation of nuclei, continued growth, and redox reactions in a hydrothermal process. The as-prepared nanocomposite powder was characterized by XRD, Raman, FTIR, and XPS measurements. All characterizations clearly confirmed that zirconia nanoparticles were successfully bonded into the reduced graphene oxide sheets during hydrothermal reaction. The uniformity distribution of $\mathrm{ZrO}_{2}$ nanoparticles, which completely cover the graphene oxide sheets, was also clearly evidenced by the SEM and TEM observations. Moreover, the lattice spacing displayed in the TEM image belongs to the tetragonal structure of zirconia with the (111) plane surface. We believe that this synthesis route will allow for the effective production of uniform ceramic/graphene nanopowders that can be used as a building block to fabricate zirconia matrix composites reinforced with a homogenous nanostructure graphene after sintering.

Author Contributions: Conceptualization, A.S., J.F.B.; data curation, N.P., Y.P.; formal analysis, N.W.S.P., P.P.; funding acquisition, P.P.; investigation, P.P., N.P.; methodology, A.S., J.F.B.; project administration, A.S., J.F.B.; resources, N.W.S.P., N.P.; software, Y.P., N.W.S.P.; supervision, A.S., J.F.B.; validation, Y.P., N.P.; visualization, P.P., N.W.S.P.; writing-original draft, A.S., J.F.B. All authors read and approved the final version of the manuscript.

Funding: We would like to thank the Ministry of Science and High Education of the Russian Federation for supporting this work under contract 075-15-2019-692 (MK-2154.2019.8).

Acknowledgments: The contributions of the Material Properties Research Laboratory GIZ MSTU “STANKIN" in the sample's characterization are greatly appreciated.

Conflicts of Interest: The authors declare no conflict of interest.

\section{References}

1. Novoselov, K.S.; Geim, A.K.; Morozov, S.V.; Jiang, D.; Zhang, Y.; Dubonos, S.V.; Grigoriev, I.V.; Firsov, A.A. Electric field effect in atomically thin carbon films. Science 2004, 306, 666-669. [CrossRef]

2. Zhu, Y.; Murali, S.; Cai, W.; Li, X.; Suk, J.W.; Potts, J.R.; Ruoff, R.S. Graphene and graphene oxide: Synthesis, properties, and applications. Adv. Mater. 2010, 22, 3906-3924. [CrossRef] [PubMed]

3. Soldano, C.; Mahmood, A.; Dujardin, E. Production, properties and potential of graphene. Carbon 2010, 48, 2127-2150. [CrossRef]

4. Choi, W.; Lahiri, I.; Seelaboyina, R.; Kang, Y.S. Synthesis of graphene and its applications: A review. Crit. Rev. Solid State Mater. Sci. 2012, 35, 52-71. [CrossRef]

5. Wei, D.; Liu, T. Controllable synthesis of graphene and its applications. Adv. Mater. 2010, 22, 3225-3241. [CrossRef] [PubMed]

6. Avouris, P.; Dimitrakopoulos, C. Graphene: Synthesis and applications. Mater. Today 2012, 15, 86-97. [CrossRef]

7. Jia, X.; Campos-Delgado, J.; Terrones, M.; Meuniere, V.; Dresselhaus, M.S. Graphene edges: A review of their fabrication and characterization. Nanoscale 2011, 3, 86-95. [CrossRef]

8. Novoselov, K.S.; Geim, A.K.; Morozov, S.V.; Jiang, D.; Katsnelson, M.I.; Grigorieva, I.; Dubonos, S.V.; Firsov, A.A. Two-dimensional gas of massless Dirac fermions in graphene. Nature 2005, 438, 197-200. [CrossRef] 
9. Edwards, R.S.; Coleman, K.S. Graphene synthesis: Relationship to applications. Nanoscale 2013, 4, 38-51. [CrossRef]

10. Huang, X.; Yin, Z.; Wu, S.; Qi, X.; He, Q.; Zhang, Q.; Yan, Q.; Boey, F.; Zhang, H. Graphene-based materials: Synthesis, characterization, properties, and applications. Small 2011, 7, 1876-1902. [CrossRef]

11. Zheng, C.; Zhou, X.; Cao, H.; Liu, Z. Applications of graphene in supercapacitors. In Graphene: Energy Storage and Conversion Applications; Liu, Z., Zhou, X., Eds.; CRC Press: Boca Raton, FL, USA, 2014; pp. 171-172.

12. Bocanegra-Bernal, M.H.; De La Torre, S.D. Phase transitions in zirconium dioxide and related materials for high performance engineering ceramics. J. Mater. Sci. 2002, 37, 4947-4971. [CrossRef]

13. Solís, N.W.; Peretyagin, P.; Torrecillas, R.; Fernández, A.; Menéndez, J.L.; Mallada, C.; Díaz, L.A.; Moya, J.S. Electrically conductor black zirconia ceramic by SPS using graphene oxide. J. Electroceram. 2017, 38, 119-124. [CrossRef]

14. Kameo, K.; Friedrich, K.; Bartolome, J.F.; Diaz, M.; Lopez-Esteban, S.; Moya, J.S. Sliding wear of ceramics and cermets against steel. J. Eur. Ceram. Soc. 2003, 23, 2867-2877. [CrossRef]

15. Pecharroman, C.; Lopez-Esteban, S.; Bartolome, J.F.; Moya, J.S. Evidence of nearest-neighbor ordering in wet-processed zirconia-nickel composites. J. Am. Ceram. Soc. 2001, 84, 2439-2441. [CrossRef]

16. Sergo, V.; Lughi, V.; Pezzotti, G.; Lucchini, E.; Meriani, S.; Muraki, N.; Katagiri, G.; Nishida, T. The effect of wear on the tetragonal-to-monoclinic transformation and the residual stress distribution in zirconia-toughened alumina cutting tools. Wear 1998, 214, 264-270. [CrossRef]

17. Chen, Z.D.; Myo, M.H.; Choy, C.M. Rapid manufacturing of Y-TZP ceramic punch using powder injection moulding technology. Mater. Sci. Forum 2003, 437, 415-418. [CrossRef]

18. Bartolome, J.F;; Montero, I.; Diaz, M.; Lopez-Esteban, S.; Moya, J.S. Accelerated aging in 3-mol\%-yttria-stabilized tetragonal zirconia ceramics sintered in reducing conditions. J. Am. Ceram. Soc. 2004, 12, 2282-2285. [CrossRef]

19. Bartolomé, J.F.; Moya, J.S.; Couceiro, R.; Gutierrez, C.F.; Guitián, F.; Martínez-Insua, M. In vitro and in vivo evaluation of a new zirconia/niobium biocermet for hard tissue replacement. Biomaterials 2016, 76, 313-320. [CrossRef]

20. Moya, J.S.; Sanchez-Herencia, J.A.; Bartolome, J.F.; Tanimoto, T. Elastic modulus in rigid $\mathrm{Al}_{2} \mathrm{O}_{3} / \mathrm{ZrO}_{2}$ ceramic laminates. Scripta Mater. 1997, 37, 1095-1103. [CrossRef]

21. Smirnov, A.; Seleznev, A.; Solis Pinargote, N.W.; Pristinskiy, Y.; Peretyagin, P.; Bartolome, J.F. The influence of wire electrical discharge machining cutting parameters on the surface roughness and flexural strength of $\mathrm{ZrO}_{2}$ /TiN ceramic nanocomposites obtained by Spark Plasma Sintering. Nanomaterials 2019, 9, 1391. [CrossRef]

22. Smirnov, A.; Kurland, H.-D.; Grabow, J.; Müller, F.A.; Bartolome, J.F. Microstructure, mechanical properties and low temperature degradation resistance of $2 \mathrm{Y}-\mathrm{TZP}$ ceramic materials derived from nanopowders prepared by laser vaporization. J. Eur. Ceram. Soc. 2015, 35, 2685-2691. [CrossRef]

23. Park, S.; Ruoff, R.S. Chemical methods for the production of graphenes. Nat. Nanotechnol. 2009, 4, $217-224$. [CrossRef] [PubMed]

24. Shahriary, L.; Athawale, A.A. Graphene oxide synthesized by using modified Hummers approach. Int. J. Renew. Energy Environ. Eng. 2014, 2, 58-63.

25. Centeno, A.; Rocha, V.G.; Alonso, B.; Fernández, A.; Gutierrez-Gonzalez, C.F.; Torrecillas, R.; Zurutuza, A. Graphene for tough and electroconductive alumina ceramics. J. Eur. Ceram. Soc. 2013, 33, 3201-3210. [CrossRef]

26. Grigoriev, S.; Peretyagin, P.; Smirnov, A.; Solis, W.; Diaz, L.A.; Fernandez, A.; Torrecillas, R. Effect of graphene addition on the mechanical and electrical properties of $\mathrm{Al}_{2} \mathrm{O}_{3}-\mathrm{SiCw}$ ceramics. J. Eur. Ceram. Soc. 2017, 37, 2473-2479. [CrossRef]

27. Miranzo, P.; Belmonte, M.; Osendi, I. From bulk to cellular structures: A review on ceramic/graphene filler composites. J. Eur. Ceram. Soc. 2017, 37, 3649-3672. [CrossRef]

28. Smirnov, A.; Peretyagin, P.; Bartolome, J.F. Processing and mechanical properties of new hierarchical metal-graphene flakes reinforced ceramic matrix composites. J. Eur. Ceram. Soc. 2019, 39, 3491-3497. [CrossRef]

29. Liu, J.; Yan, H.; Reece, M.J.; Jiang, K. Toughening of zirconia/alumina composites by the addition of graphene platelets. J. Eur. Ceram. Soc. 2012, 32, 4185-4193. [CrossRef]

30. Walker, L.S.; Marotto, V.R.; Rafiee, M.A.; Koratkar, N.; Corral, E.L. Toughening in graphene ceramic composites. ACS Nano 2011, 5, 3182-3190. [CrossRef] 
31. Shin, J.H.; Hong, S.H. Fabrication and properties of reduced graphene oxide reinforced yttria-stabilized zirconia composite ceramics. J. Eur. Ceram. Soc. 2014, 34, 1297-1302. [CrossRef]

32. Kwon, S.M.; Lee, S.J.; Shon, I.J. Enhanced properties of nanostructured $\mathrm{ZrO}_{2}$-graphene composites rapidly sintered via high-frequency induction heating. Ceram. Int. 2015, 41, 835-842. [CrossRef]

33. Chen, F.; Jin, D.; Tyeb, K.; Wang, B.; Han, Y.-Y.; Kim, S.; Schoenung, J.M.; Shen, Q.; Zhang, L. Field assisted sintering of graphene reinforced zirconia ceramics. Ceram. Int. 2015, 41, 6113-6116. [CrossRef]

34. Rincón, A.; Moreno, R.; Gutiérrez-González, C.F.; Sainz, R.; Salvador, M.D.; Borrell, A. Colloidal processing of fully stabilized zirconia laminates comprising graphene oxide-enriched layers. J. Eur. Ceram. Soc. 2016, 36, 1797-1804. [CrossRef]

35. Khan Rao, R.A.; Singh, S.; Singh, B.R.; Khan, W.; Naqvi, A.H. Synthesis and characterization of surface modified graphene-zirconium oxide nanocomposite and its possible use for the removal of chlorophenol from aqueous solution. J. Environ. Chem. Eng. 2014, 2, 199-210.

36. Teymourian, H.; Salimi, A.; Firoozi, S.; Korani, A.; Soltanian, S. One-pot hydrothermal synthesis of zirconium dioxide nanoparticles decorated reduced graphene oxide composite as high performance electrochemical sensing and biosensing platform. Electrochim. Acta 2014, 143, 196-206. [CrossRef]

37. Li, H.; Xie, Y.; Li, K.; Huang, S.; Zhao, B.; Zheng, X. Microstructure and wear behavior of graphene nanosheets-reinforced zirconia coating. Ceram. Int. 2014, 40, 12821-12829. [CrossRef]

38. Limaye, A.U.; Helble, J.J. Effect of precursor and solvent on morphology of zirconia nanoparticles produced by combustion aerosol synthesis. J. Am. Ceram. Soc. 2003, 86, 273-278. [CrossRef]

39. Heshmatpour, F.; Aghakhanpour, R.B. Synthesis and characterization of nanocrystalline zirconia powder by simple sol-gel method with glucose and fructose as organic additives. Powder Tech. 2011, 205, 193-200. [CrossRef]

40. Keskinen, H.; Moravec, P.; Smolík, J.; Levdansky, V.V.; Mäkelä, J.M.; Keskinen, J. Preparation of $\mathrm{ZrO}_{2}$ fine particles by CVD process: Thermal decomposition of zirconium tert-butoxide vapor. J. Mater. Sci. 2004, 39, 4923-4929. [CrossRef]

41. Nimmo, W.; Hind, D.; Ali, N.J.; Hampartsoumian, E.; Milne, S.J. The production of ultrafine zirconium oxide powders by spray pyrolysis. J. Mater. Sci. 2002, 37, 3381-3387. [CrossRef]

42. Tai, C.Y.; Hsiao, B.-Y.; Chiu, H.-Y. Preparation of spherical hydrous-zirconia nanoparticles by low temperature hydrolysis in a reverse microemulsion. Colloids Surf. A: Physicochem. Eng Asp. 2004, 237, 105-111. [CrossRef]

43. Dittmar, A.; Hoang, D.L.; Martin, A. TPR and XPS characterization of chromia-lanthana-zirconia catalyst prepared by impregnation and microwave plasma enhanced chemical vapour deposition methods. Thermochim Acta 2008, 470, 40-46. [CrossRef]

44. Piticescu, R.R.; Monty, C.; Taloi, D.; Motoc, A.; Axinte, S. Hydrothermal synthesis of zirconia nanomaterials. J. Eur. Ceram. Soc. 2001, 21, 2057-2060. [CrossRef]

45. Sagadevan, S.; Podder, J.; Das, I. Hydrothermal synthesis of zirconium oxide nanoparticles and its characterization. J. Mater. Sci.: Mater. Electr. 2016, 27, 5622-5627. [CrossRef]

46. Hummers, W.S., Jr.; Offeman, R.E. Preparation of graphitic oxide. J. Am. Chem. Soc. 1958, 80, 1339. [CrossRef]

47. Botas, C.; Pérez-Mas, A.M.; Álvarez, P.; Santamaría, R.; Granda, M.; Blanco, C.; Menéndez, R. Optimization of the size and yield of graphene oxide sheets in the exfoliation step. Carbon 2013, 63, 576-578. [CrossRef]

48. Grigoriev, S.N.; Volosova, M.A.; Peretyagin, P.Y.; Seleznev, A.E.; Okunkova, A.A.; Smirnov, A. The effect of $\mathrm{TiC}$ additive on mechanical and electrical properties of $\mathrm{Al}_{2} \mathrm{O}_{3}$ ceramic. Appl. Sci. 2018, 8, 2385. [CrossRef]

49. Bartolomé, J.F.; Smirnov, A.; Kurland, H.-D.; Grabow, J.; Müller, F.A. New $\mathrm{ZrO}_{2} / \mathrm{Al}_{2} \mathrm{O}_{3}$ nanocomposite fabricated from hybrid nanoparticles prepared by $\mathrm{CO}_{2}$ laser co-vaporization. Sci. Rep. 2016, 6, 20589. [CrossRef]

50. Wang, Z.L.; Quan, Z.W.; Lin, J. Remarkable changes in the optical properties of CeO2 nanocrystals induced by lanthanide ions doping. Inorg. Chem. 2007, 46, 5237. [CrossRef]

51. Phoka, S.; Laokul, P.; Swatsitang, E.; Promarak, V.; Seraphin, S.; Maensiri, S. Synthesis, structural and optical properties of $\mathrm{CeO}_{2}$ nanoparticles synthesized by a simple polyvinyl pyrrolidone (PVP) solution route. Mater. Chem. Phys. 2009, 115, 423. [CrossRef]

52. Kumar, S.; Sharma, J.G.; Maji, S.; Malhotra, B.D. Nanostructured zirconia decorated reduced graphene oxide based efficient biosensing platform for non-invasive oral cancer detection. Biosens. Bioelectron. 2016, $15,497$. [CrossRef] [PubMed] 
53. Yang, J.; Pruvost, S.; Livi, S.; Duchet-Rumeau, J. The Role of fluorinated IL as an interfacial agent in P(VDF-CTFE)/Graphene composite films. Nanomaterials 2019, 9, 1181. [CrossRef] [PubMed]

54. Krishnamoorthy, K.; Veerapandian, M.; Yun, K.; Kim, S.J. The chemical and structural analysis of graphene oxide with different degrees of oxidation. Carbon 2013, 53, 38-49. [CrossRef]

55. Kaniyoor, A.; Ramaprabhu, S. A Raman spectroscopic investigation of graphite oxide derived graphene. AIP Adv. 2012, 2, 032183. [CrossRef]

56. Johra, F.T.; Lee, J.-W.; Jung, W.-G. Facile and safe graphene preparation on solution-based platform. J. Industr. Eng. Chem. 2014, 20, 2883-2887. [CrossRef]

57. Basahel, S.N.; Ali, T.T.; Mokhtar, M.; Narasimharao, K. Influence of crystal structure of nanosized $\mathrm{ZrO}_{2}$ on photocatalytic degradation of methyl orange. Nanoscale Res. Lett. 2015, 10, 73. [CrossRef]

58. Bugrov, A.N.; Smyslov, R.Y.; Zavialova, A.Y.; Kopitsa, G.P. The influence of chemical prehistory on the structure, photoluminescent properties, surface and biological characteristics of $\mathrm{Zr0.98Eu0.02 \textrm {O } 1 . 9 9}$ nanophosphors. Nanosyst. Phys. Chem. Math. 2019, 10, 164-175. [CrossRef]

59. Zeng, Z.; Liu, Y.; Chen, W.; Li, X.; Zheng, Q.; Li, K.; Guo, R. Fabrication and properties of in situ reduced graphene oxide-toughened zirconia composite ceramics. J. Am. Ceram. Soc. 2018, 101, 3498-3507. [CrossRef]

60. Gurushantha, K.; Anantharaju, K.S.; Renuka, L.; Sharma, S.C.; Nagaswarupa, H.P.; Prashantha, S.C.; Vidya, Y.S.; Nagabhushana, H. One pot synthesized reduced graphene oxide- $\mathrm{ZrO}_{2}$ composite as high performance photocatalyst under sunlight. RSC Adv. 2017, 21, 12690-12703. [CrossRef]

61. Hu, C.; Liu, Y.; Yang, Y.; Cui, J.; Huang, Z.; Wang, Y.; Yang, L.; Wang, H.; Xiaob, Y.; Rong, J. One-step preparation of nitrogen-doped graphene quantum dots from oxidized debris of graphene oxide. J. Mater. Chem. 2013, B1, 39-42. [CrossRef]

62. Rani, J.R.; Lim, J.; Oh, J.; Kim, J.-W.; Shin, H.S.; Kim, J.H.; Lee, S.; Jun, S.C. Epoxy to carbonyl group conversion in graphene oxide thin films: Effect on structural and luminescent characteristics. J. Phys. Chem. 2012, C116, 19010-19017. [CrossRef]

63. Xu, B.; Yue, S.; Sui, Z.; Zhang, X.; Hou, S.; Cao, G.; Ya, Y. What is the choice for supercapacitors: Graphene or graphene oxide? Energy Environ. Sci. 2011, 4, 2826-2830. [CrossRef]

64. Fan, X.; Peng, W.; Li, Y.; Li, X.; Wang, S.; Zhang, G.; Zhang, F. Deoxygenation of exfoliated graphite oxide under alkaline conditions: A green route to graphene preparation. Adv. Mater. 2008, 20, 4490-4493. [CrossRef]

65. Takashi Ogi, T.; Iwasaki, H.; Aishima, K.; Iskandar, F.; Wang, W.-N.; Takimiya, K.; Okuyama, K. Transient nature of graphene quantum dot formation via a hydrothermal reaction. RSC Adv. 2014, 4, 55709-55715.

66. Ju, J.; Zhang, R.; He, S.; Chen, W. Nitrogen-doped graphene quantum dots-based fluorescent probe for the sensitive turn-on detection of glutathione and its cellular imaging. RSC Adv. 2014, 4, 52583-52589. [CrossRef]

67. Gong, P.; Hou, K.; Ye, X.; Ma, L.; Wang, J.; Yanga, S. Synthesis of highly luminescent fluorinated graphene quantum dots with tunable fluorine coverage and size. Mater. Lett. 2015, 143, 112-115. [CrossRef]

68. Zheng, Y.; Jiao, Y.; Ge, L.; Jaroniec, M.; Qiao, S.Z. Two-Step Boron and Nitrogen Doping in Graphene for Enhanced Synergistic Catalysis. Angew. Chem. 2013, 125, 3192-3198. [CrossRef]

69. Waltman, R.J.; Pacansky, J.; Bates, C.W., Jr. X-ray photoelectron spectroscopic studies on organic photoconductors: Evaluation of atomic charges on chlorodiane blue and p-(diethylamino)benzaldehyde diphenylhydrazone. Chem. Mater. 1993, 5, 1799-1804. [CrossRef]

70. Liu, C.; Li, K.; Li, H.; Zhang, S.; Zhang, Y.; Wang, B. Synthesis, characterization and ceramization of a carbon-rich zirconium-containing precursor for ZrC ceramic. Ceram. Int. 2014, 40, 7285-7292. [CrossRef]

71. Singh, R.R.K.; Singh, P. Electrical conductivity of LSGM-YSZ composite materials synthesized via coprecipitation route. J. Mater. Sci. 2014, 49, 5571-5578.

72. Gao, Y.; Chen, K.; Tan, X.; Wang, X.; Alsaedi, A.; Hayat, T.; Chen, C. Interaction mechanism of Re(VII) with zirconium dioxide nanoparticles archored onto reduced graphene oxides. ACS Sustain. Chem. Eng. 2017, 5, 2163-2171. [CrossRef]

73. Wang, S.F.; Gu, F.; Lü, M.K.; Yang, Z.S.; Zhou, G.J.; Zhang, H.P.; Zhou, Y.Y.; Wang, S.M. Structure evolution and photoluminescence properties of $\mathrm{ZrO}_{2}: \mathrm{Eu}^{3+}$ nanocrystals. Opt. Mater. 2006, 28, 1222-1226. [CrossRef]

74. Yang, Q.; Wang, Z.; Weng, J. Self-assembly of natural tripeptide glutathione triggered by graphene oxide. Soft Matter 2012, 8, 9855-9863. [CrossRef]

75. Maity, S.K.; Rana, M.S.; Srinivas, B.N.; Bej, S.K.; Dhar, G.M.; Prasada Rao, T.S.R. Characterization and evaluation of $\mathrm{ZrO}_{2}$ supported hydrotreating catalysts. J. Mol. Catal. A Chem. 2000, 153, 121-127. [CrossRef] 
76. Song, H.J.; Jia, X.H.; Li, N.; Yang, X.F.; Tang, H. Synthesis of $\alpha-\mathrm{Fe}_{2} \mathrm{O}_{3}$ nanorod/graphene oxide composites and their tribological properties. J. Mater. Chem. 2012, 22, 895-902. [CrossRef]

77. Jang, S.; Sohn, H.; Ko, Y.K. Synthesis and characterization of soluble alkylalcohol-derivatized graphene oxide. Bull. Korean Chem. Soc. 2013, 34, 1237. [CrossRef]

78. Suneetha, R.B. Spectral, thermal and morphological characterization of biodegradable graphene oxide-chitosan nanocomposites. J. Nanosci. Technol. 2018, 4, 342-344. [CrossRef]

79. Amer Al-Nafiey, A.; Al-Mamoori, M.H.K.; Alshrefi, S.M.; Shakir, A.K.; Ahmed, R.T. One step to synthesis (rGO/Ni NPs) nanocomposite and using to adsorption dyes from aqueous solution. Mater. Today Proceed. 2019, 19, 94-101. [CrossRef]

80. Mohamadi, M.; Kowsari, E.; di-Asl, V.; Yousefzadeh, M.; Chinnappan, A.; Ramakrishna, S. Highly-efficient microwave absorptivity in reduced graphene oxide modified with PTA@ imidazolium based dicationic ionic liquid and fluorine atom. Compos. Sci. Technol. 2020, 188, 107960. [CrossRef]

81. Lingaraju, K.; Naika, H.R.; Nagaraju, G.; Nagabhushana, H. Biocompatible synthesis of reduced graphene oxide from Euphorbia heterophylla (L.) and their in-vitro cytotoxicity against human cancer cell lines. Biotech. Rep. 2019, 24, e00376. [CrossRef]

82. Walantina, E.; Dhineshbabu, N.R. Photonic band gap analysis of graphene oxide nanostructures using opti-FDTD. In Proceedings of the International Conference on Green Engineering and Technologies (IC-GET), Coimbatore, India, 19 November 2016.

83. Verma, D.S.; Khan, L.U.; Kumar, S.; Khan, S.B. Fourier transform infrared spectroscopy: Fundamentals and applications in functional groups and nanomaterials characterization. In Handbook of Materials Characterization, 1st ed.; Springer International Publishing: New York, NY, USA, 2018.

84. Huang, Q.; Gao, L. Immobilization of rutile $\mathrm{TiO}_{2}$ on multiwalled carbon nanotubes. J. Mater. Chem. 2003, 13, 1517-1519. [CrossRef]

85. Chandra, V.; Park, J.; Chun, Y.; Lee, J.W.; Hwang, I.-C.; Kim, K.S. Water-dispersible magnetite-reduced graphene oxide composites for arsenic removal. ACS Nano 2010, 7, 3979-3986. [CrossRef] [PubMed]

86. Park, S.; An, J.; Jung, I.; Piner, R.D.; An, S.J.; Li, X.; Velamakanni, A.; Ruoff, R.S. Colloidal suspensions of highly reduced graphene oxide in a wide variety of organic solvents. Nano Lett. 2009, 9, 1593-1597. [CrossRef] [PubMed]

87. Bai, G.Y.; Wang, J.Q.; Yang, Z.G.; Wang, H.G.; Wang, Z.F.; Yang, S.R. Preparation of a highly effective lubricating oil additive-ceria/graphene composite. RSC Adv. 2014, 4, 47096-47105. [CrossRef]

88. Kasatkin, I.; Girgsdies, F.; Ressler, T.; Caruso, R.A.; Schattka, J.; Urban, J.; Weiss, K. HRTEM observation of the monoclinic-to-tetragonal (m-t) phase transition in nanocrystalline $\mathrm{ZrO}_{2}$. J. Mater. Sci. 2004, 39, 2151-2157. [CrossRef]

89. Gutierrez-Gonzalez, C.F.; Smirnov, A.; Centeno, A.; Fernández, A.; Alonso, B.; Rocha, V.G.; Torrecillas, R.; Zurutuza, A.; Bartolome, J.F. Wear behavior of graphene/alumina composite. Ceram. Inter. 2015, 41, 7434-7438. [CrossRef]

(C) 2020 by the authors. Licensee MDPI, Basel, Switzerland. This article is an open access article distributed under the terms and conditions of the Creative Commons Attribution (CC BY) license (http://creativecommons.org/licenses/by/4.0/). 